\title{
Why do snails have hairs? A Bayesian inference of character evolution
}

\author{
Markus Pfenninger*1, Magda Hrabáková2 ${ }^{2}$ Dirk Steinke ${ }^{3}$ and Aline Dèpraz ${ }^{4}$
}

Address: ${ }^{1}$ Abteilung Ökologie \& Evolution, J.W. Goethe-Universität, BioCampus Siesmayerstraße, 60054 Frankfurt/Main, Germany, ${ }^{2}$ Deparment of Zoology, Charles University, Viniènà 7, 12844 Praha 2, Czech Republic, ${ }^{3}$ Department of Biology, University of Konstanz, Postbox 5560 M618, 78457 Konstanz, Germany and ${ }^{4}$ Département d'Ecologie et Evolution, Université de Lausanne, Bâtiment de Biologie, Dorigny, 1015 Lausanne, Switzerland

Email: Markus Pfenninger* - Pfenninger@zoology.uni-frankfurt.de; Magda Hrabáková - Magda.Hrabakova@seznam.cz; Dirk Steinke - Dirk.Steinke@uni-konstanz.de; Aline Dèpraz - Aline.Depraz@unil.ch

* Corresponding author

Published: 04 November 2005

BMC Evolutionary Biology 2005, 5:59 doi:10.1186/147/-2/48-5-59
Received: 14 July 2005

Accepted: 04 November 2005

This article is available from: http://www.biomedcentral.com/I47/-2/48/5/59

(c) 2005 Pfenninger et al; licensee BioMed Central Ltd.

This is an Open Access article distributed under the terms of the Creative Commons Attribution License (http://creativecommons.org/licenses/by/2.0), which permits unrestricted use, distribution, and reproduction in any medium, provided the original work is properly cited.

\begin{abstract}
Background: Costly structures need to represent an adaptive advantage in order to be maintained over evolutionary times. Contrary to many other conspicuous shell ornamentations of gastropods, the haired shells of several Stylommatophoran land snails still lack a convincing adaptive explanation. In the present study, we analysed the correlation between the presence/absence of hairs and habitat conditions in the genus Trochulus in a Bayesian framework of character evolution.

Results: Haired shells appeared to be the ancestral character state, a feature most probably lost three times independently. These losses were correlated with a shift from humid to dry habitats, indicating an adaptive function of hairs in moist environments. It had been previously hypothesised that these costly protein structures of the outer shell layer facilitate the locomotion in moist habitats. Our experiments, on the contrary, showed an increased adherence of haired shells to wet surfaces.

Conclusion: We propose the hypothesis that the possession of hairs facilitates the adherence of the snails to their herbaceous food plants during foraging when humidity levels are high. The absence of hairs in some Trochulus species could thus be explained as a loss of the potential adaptive function linked to habitat shifts.
\end{abstract}

\section{Background}

Evolutionary theory predicts that costly structures must convey a fitness advantage to their bearers in order to be maintained over evolutionary time [1]. Flightlessness in birds and insects, limblessness in lizards and sightlessness in cave-dwelling organisms are some prominent examples of phenotypic regression due to the loss of adaptive function (reviewed in [2]). Molluscs in general and gastropods in particular display a fascinating diversity of elaborate shell structures $[3,4]$ and have attracted considerable research efforts to explain them in adaptive terms [5-7]. The proposed roles invoked mechanical stability [8], defence against predators [9], sexual selection [10] and climatic selection [11]. However, the potential selective advantage of hair-like shell ornamentation of certain land snail species remains unknown. 


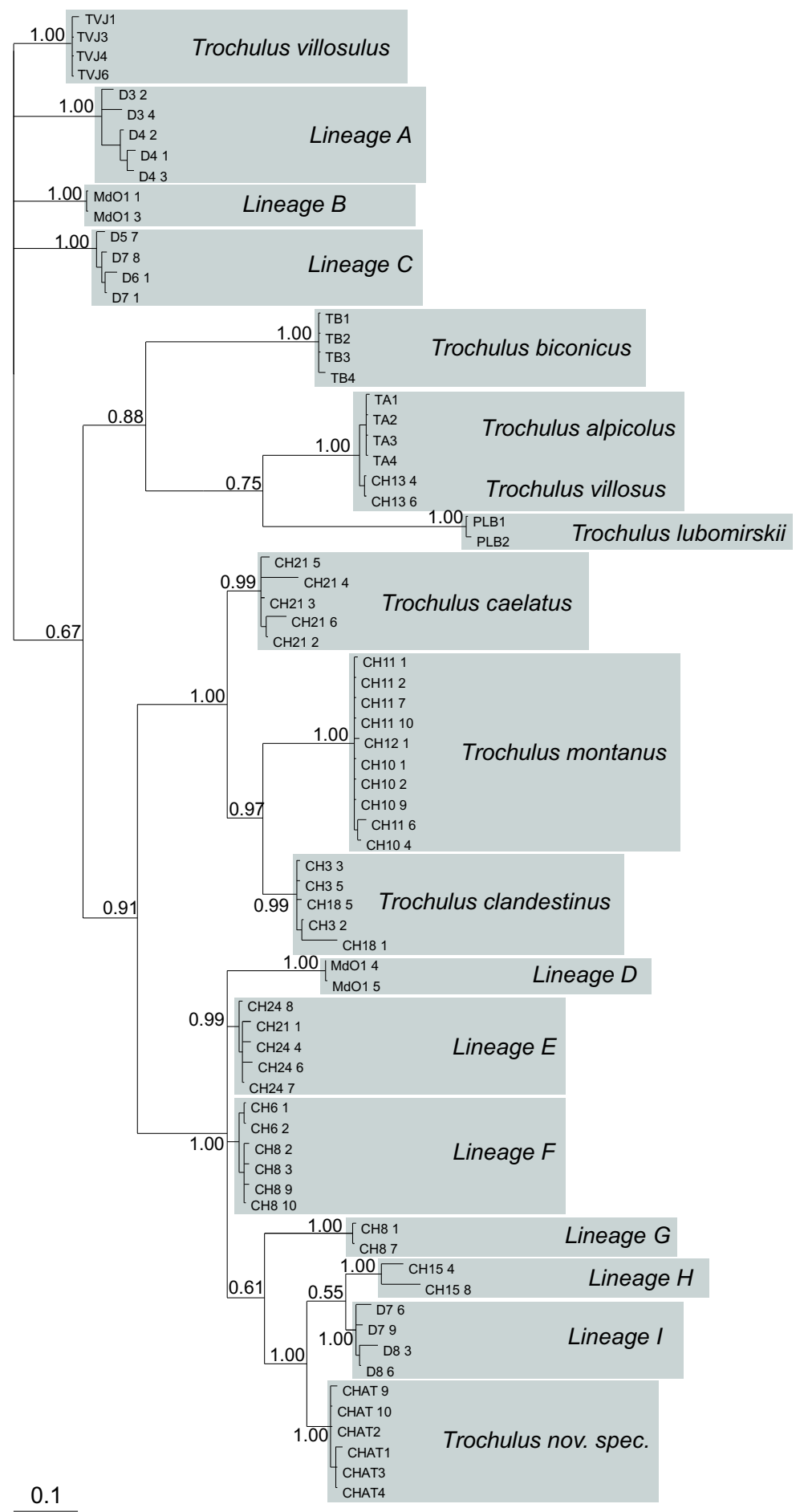

Figure I

Unrooted consensus tree of $\mathbf{9 0 , 0 0 0}$ trees sampled by the Markov-chain in Bayesian analysis for the COI-fragment. Numbers on nodes indicate the Bayesian posterior probability. 
These hairs can reach varying densities (up to 20 per squaremilimetre) and lengths (up to three millimetres). In some cases hardly visible, they confer an almost furry impression to the shell in others. These semi-rigid structures are part of the periostracum, a thin protein layer (conchiolin) secreted by the snail to cover the calcareous shell [12]. Building hairs requires the snail to have specialised glandular tissue and complex strategies to form them. Consequently, this trait can be assumed to be costly and should thus present a selective advantage to its bearers in order to be conserved.

Haired shells occur in several species of the Stylommatophoran families Polygyridae, Helicidae and Hygromiidae. These families are only distantly related [13], suggesting that this features has evolved several times independently. Haired shells are almost exclusively observed in species living in moist microhabitats, like layers of fallen leaves, broad-leaved vegetation, damp meadows or wet scree [14]. Such a correlation suggests an adaptive significance of the trait in such a habitat [1]; it was thus speculated that the hygrophobic hairs facilitate the movement in wet environments by relieving surface tension $[14,15]$. A correlation between haired shells and humid habitats is thus expected. In order to test this, we employed the recent Bayesian extensions of the comparative method, allowing to take mapping and phylogenetic uncertainty simultaneously into account [16]. With a diversity hotspot in South Germany, Eastern France and Switzerland, the land snail genus Trochulus s. str. (common name: Hairy snails) is particularly suited to address our question: its species exhibit variability in both hairiness and ecology. This study present the first comprehensive molecular phylogeny for the genus Trochulus Chemnitz, 1786 (until recently Trichia, Hartmann 1840) based on mitochondrial and nuclear loci. Finally, we tested experimentally whether the possession of haired shells indeed facilitates locomotion.

\section{Results}

\section{Lineage identification and phylogenetic relations}

The initial phylogenetic analysis on a COI data set of the presumed Trochulus species resolved 18 terminal clades, each with 0.99 posterior probabilities or higher (Figure $1)$. The uncorrected sequence divergence among those clades ranged from 0.029 to 0.173 (Table 2). Out of these lineages, nine could be assigned to existing taxa, because the species were sampled from the type locality and/or were morphologically unmistakable. The nine remaining clades, however, could not be unequivocally attributed to a taxonomic name. All eighteen identified lineages were used as molecularly defined operational taxonomic units in the subsequent analyses [17].

The Bayesian phylogenetic analysis of the entire data set (COI, 16S and ITS-1) showed the monophyly of the genus
Trochulus within the Hygromiinae with high posterior probability, except for T. lubomirskii, which seems to be only distantly related to this genus (Figure 2). In addition to the early branching T. villosus/alpicolus clade, the genus is composed of three well supported subclades: first, a clade containing the T. striolatus/plebeius-like lineages together with $T$. villosulus, a second clade with ecologically divers species confined to the Jura mountains and the neighbouring Mittelland-plain and finally, a T. hispidus/ sericeus-like clade, containing also T. biconicus and a new species.

\section{Correlation of shell hairiness with habitat}

The PCA on habitat humidity describing variables resulted in two meaningful axes, representing $79.7 \%$ and $13.4 \%$ of the total variation. The first component opposed sampling sites in shady woods and sites in sun exposed, open areas. This axis can therefore be interpreted as an evaporation gradient. The second axis is a gradient of the summer precipitation on one hand and the humidity demand of the vegetation on the other (Figure 3 ). It can thus be considered as a humidity gradient. The sampling sites appear as two distinct clusters that could be classified as either moist or dry (Table 1). The outlier (TA) was also considered to be humid, according to its high humidity levels. For each population, at least ten adult individuals were scored for the presence or absence of hairs (mixed populations were not found). Non-haired populations exclusively corresponded to species described in the literature as having smooth shells (Table 1). When plotting the hairiness of each population on the PCA, a complete congruence between humidity and hairiness became apparent: haired shells tended to occur at sites with low evaporation and/or high precipitation while smooth shells were found at places with high evaporation and/or lower precipitation (Figure 3).

\section{Character state evolution}

As the occurrence in moist habitats was systematically linked to the presence of hairs in Trochulus s.str., only a single analysis was necessary for both characters. The Bayesian analysis of character evolution suggested with high posterior probability that the most recent common ancestor of the genus Trochulus most likely possessed hairs and lived in a moist habitat (Figure 4). The analysis also revealed considerable mapping- and/or phylogenetic uncertainty in the reconstruction of crucial ancestral nodes (nodes 1-3 in Figure 4). The average Bayesian parameter estimate for the character change ratio was 2.50 \pm 0.11 (mean \pm s.d.), indicating that a loss of hairs associated with a transition from wet to dry habitats occurred more frequently than vice versa. This was in concordance with the parsimony reconstruction of character state changes on all different topologies of the $99 \%$ credibility set of trees. A minimum number of three independent 
Table 2: Pairwise uncorrected COI sequence divergence among lineages and species (mean \pm s.d.).

\begin{tabular}{|c|c|c|c|c|c|c|c|c|c|c|c|c|c|c|c|c|}
\hline & $A$ & $B$ & $C$ & villosulus & montanus & clandest. & caelatus & $D$ & $E$ & $F$ & $G$ & $H$ & 1 & biconicus & nov. spec. & villosus \\
\hline B & $\begin{array}{l}0.1111 \pm \\
0.015\end{array}$ & & $\begin{array}{l}\text { striolatus/ } \\
\text { plebeius }\end{array}$ & & & & & & & & & & & & & \\
\hline$c$ & $\begin{array}{l}0.118 \pm \\
0.015\end{array}$ & $\begin{array}{l}0.091 \pm \\
0.013\end{array}$ & clade & & & & & & & & & & & & & \\
\hline villosulus & $\begin{array}{l}0.104 \pm \\
0.014\end{array}$ & $\begin{array}{l}0.073 \pm \\
0.013\end{array}$ & $\begin{array}{l}0.091 \pm \\
0.014\end{array}$ & & & & & & & & & & & & & \\
\hline montanus & $\begin{array}{l}0.143 \pm \\
0.017\end{array}$ & $\begin{array}{l}0.144 \pm \\
0.017\end{array}$ & $\begin{array}{l}0.138 \pm \\
0.017\end{array}$ & $\begin{array}{l}0.117 \pm \\
0.016\end{array}$ & & & & & & & & & & & & \\
\hline clandestinus & $\begin{array}{l}0.135 \pm \\
0.017\end{array}$ & $\begin{array}{l}0.129 \pm \\
0.016\end{array}$ & $\begin{array}{l}0.140 \pm \\
0.017\end{array}$ & $\begin{array}{l}0.125 \pm \\
0.016\end{array}$ & $\begin{array}{l}0.083 \pm \\
0.014\end{array}$ & $\begin{array}{l}\text { Jura } \\
\text { clade }\end{array}$ & & & & & & & & & & \\
\hline caelatus & $\begin{array}{l}0.144 \pm \\
0.016\end{array}$ & $\begin{array}{l}0.152 \pm \\
0.018\end{array}$ & $\begin{array}{l}0.141 \pm \\
0.017\end{array}$ & $\begin{array}{l}0.130 \pm \\
0.016\end{array}$ & $\begin{array}{l}0.092 \pm \\
0.014\end{array}$ & $\begin{array}{l}0.093 \pm \\
0.013\end{array}$ & & & & & & & & & & \\
\hline$D$ & $\begin{array}{l}0.146 \pm \\
0.017\end{array}$ & $\begin{array}{l}0.105 \pm \\
0.016\end{array}$ & $\begin{array}{l}0.125 \pm \\
0.016\end{array}$ & $\begin{array}{l}0.127 \pm \\
0.017\end{array}$ & $\begin{array}{l}0.142 \pm \\
0.017\end{array}$ & $\begin{array}{l}0.126 \pm \\
0.016\end{array}$ & $\begin{array}{l}0.138 \pm \\
0.017\end{array}$ & & & & & & & & & \\
\hline$E$ & $\begin{array}{l}0.148 \pm \\
0.017\end{array}$ & $\begin{array}{l}0.109 \pm \\
0.016\end{array}$ & $\begin{array}{l}0.135 \pm \\
0.016\end{array}$ & $\begin{array}{l}0.117 \pm \\
0.016\end{array}$ & $\begin{array}{l}0.134 \pm \\
0.016\end{array}$ & $\begin{array}{l}0.104 \pm \\
0.014\end{array}$ & $\begin{array}{l}0.107 \pm \\
0.015\end{array}$ & $\begin{array}{l}0.079 \pm \\
0.013\end{array}$ & & & & & & $\begin{array}{l}\text { sericeus/ } \\
\text { hispidus }\end{array}$ & & \\
\hline$F$ & $\begin{array}{l}0.152 \pm \\
0.017\end{array}$ & $\begin{array}{l}0.112 \pm \\
0.015\end{array}$ & $\begin{array}{l}0.126 \pm \\
0.015\end{array}$ & $\begin{array}{l}0.119 \pm \\
0.016\end{array}$ & $\begin{array}{l}0.146 \pm \\
0.016\end{array}$ & $\begin{array}{l}0.113 \pm \\
0.015\end{array}$ & $\begin{array}{l}0.114 \pm \\
0.015\end{array}$ & $\begin{array}{l}0.072 \pm \\
0.013\end{array}$ & $\begin{array}{l}0.029 \pm \\
0.008\end{array}$ & & & & & clade & & \\
\hline$G$ & $\begin{array}{l}0.142 \pm \\
0.017\end{array}$ & $\begin{array}{l}0.139 \pm \\
0.017\end{array}$ & $\begin{array}{l}0.136 \pm \\
0.018\end{array}$ & $\begin{array}{l}0.109 \pm \\
0.016\end{array}$ & $\begin{array}{l}0.132 \pm \\
0.017\end{array}$ & $\begin{array}{l}0.117 \pm \\
0.016\end{array}$ & $\begin{array}{l}0.147 \pm \\
0.016\end{array}$ & $\begin{array}{l}0.120 \pm \\
0.017\end{array}$ & $\begin{array}{l}0.111 \pm \\
0.016\end{array}$ & $\begin{array}{l}0.105 \pm \\
0.015\end{array}$ & & & & & & \\
\hline$H$ & $\begin{array}{l}0.164 \pm \\
0.017\end{array}$ & $\begin{array}{l}0.153 \pm \\
0.018\end{array}$ & $\begin{array}{l}0.170 \pm \\
0.017\end{array}$ & $\begin{array}{l}0.169 \pm \\
0.018\end{array}$ & $\begin{array}{l}0.162 \pm \\
0.017\end{array}$ & $\begin{array}{l}0.126 \pm \\
0.015\end{array}$ & $\begin{array}{l}0.147 \pm \\
0.017\end{array}$ & $\begin{array}{l}0.116 \pm \\
0.015\end{array}$ & $\begin{array}{l}0.100 \pm \\
0.014\end{array}$ & $\begin{array}{l}0.101 \pm \\
0.014\end{array}$ & $\begin{array}{l}0.128 \pm \\
0.016\end{array}$ & & & & & \\
\hline I & $\begin{array}{l}0.150 \pm \\
0.017\end{array}$ & $\begin{array}{l}0.151 \pm \\
0.017\end{array}$ & $\begin{array}{l}0.155 \pm \\
0.017\end{array}$ & $\begin{array}{l}0.144 \pm \\
0.017\end{array}$ & $\begin{array}{l}0.148 \pm \\
0.016\end{array}$ & $\begin{array}{l}0.124 \pm \\
0.015\end{array}$ & $\begin{array}{l}0.133 \pm \\
0.016\end{array}$ & $\begin{array}{l}0.106 \pm \\
0.014\end{array}$ & $\begin{array}{l}0.102 \pm \\
0.014\end{array}$ & $\begin{array}{l}0.099 \pm \\
0.013\end{array}$ & $\begin{array}{l}0.106 \pm \\
0.014\end{array}$ & $\begin{array}{l}0.061 \pm \\
0.010\end{array}$ & & & & \\
\hline biconicus & $\begin{array}{l}0.158 \pm \\
0.018\end{array}$ & $\begin{array}{l}0.136 \pm \\
0.017\end{array}$ & $\begin{array}{l}0.141 \pm \\
0.018\end{array}$ & $\begin{array}{l}0.128 \pm \\
0.018\end{array}$ & $\begin{array}{l}0.164 \pm \\
0.020\end{array}$ & $\begin{array}{l}0.154 \pm \\
0.018\end{array}$ & $\begin{array}{l}0.167 \pm \\
0.019\end{array}$ & $\begin{array}{l}0.145 \pm \\
0.017\end{array}$ & $\begin{array}{l}0.145 \pm \\
0.018\end{array}$ & $\begin{array}{l}0.145 \pm \\
0.018\end{array}$ & $\begin{array}{l}0.143 \pm \\
0.018\end{array}$ & $\begin{array}{l}0.179 \pm \\
0.018\end{array}$ & $\begin{array}{l}0.167 \pm \\
0.017\end{array}$ & & & \\
\hline nov. spec. & $\begin{array}{l}0.153 \pm \\
0.017\end{array}$ & $\begin{array}{l}0.137 \pm \\
0.017\end{array}$ & $\begin{array}{l}0.151 \pm \\
0.017\end{array}$ & $\begin{array}{l}0.142 \pm \\
0.017\end{array}$ & $\begin{array}{l}0.151 \pm \\
0.016\end{array}$ & $\begin{array}{l}0.128 \pm \\
0.015\end{array}$ & $\begin{array}{l}0.137 \pm \\
0.016\end{array}$ & $\begin{array}{l}0.100 \pm \\
0.015\end{array}$ & $\begin{array}{l}0.082 \pm \\
0.014\end{array}$ & $\begin{array}{l}0.081 \pm \\
0.013\end{array}$ & $\begin{array}{l}0.106 \pm \\
0.015\end{array}$ & $\begin{array}{l}0.080 \pm \\
0.013\end{array}$ & $\begin{array}{l}0.057 \pm \\
0.011\end{array}$ & $\begin{array}{l}0.161 \pm \\
0.018\end{array}$ & & \\
\hline villosus & $\begin{array}{l}0.144 \pm \\
0.018\end{array}$ & $\begin{array}{l}0.139 \pm \\
0.018\end{array}$ & $\begin{array}{l}0.154 \pm \\
0.018\end{array}$ & $\begin{array}{l}0.152 \pm \\
0.018\end{array}$ & $\begin{array}{l}0.160 \pm \\
0.018\end{array}$ & $\begin{array}{l}0.153 \pm \\
0.018\end{array}$ & $\begin{array}{l}0.160 \pm \\
0.018\end{array}$ & $\begin{array}{l}0.168 \pm \\
0.019\end{array}$ & $\begin{array}{l}0.149 \pm \\
0.018\end{array}$ & $\begin{array}{l}0.151 \pm \\
0.018\end{array}$ & $\begin{array}{l}0.173 \pm \\
0.019\end{array}$ & $\begin{array}{l}0.171 \pm \\
0.019\end{array}$ & $\begin{array}{l}0.165 \pm \\
0.018\end{array}$ & $\begin{array}{l}0.163 \pm \\
0.019\end{array}$ & $\begin{array}{l}0.168 \pm \\
0.019\end{array}$ & $\begin{array}{l}\text { villosal } \\
\text { alpicola }\end{array}$ \\
\hline alpicolus & $\begin{array}{l}0.142 \pm \\
0.016\end{array}$ & $\begin{array}{l}0.141 \pm \\
0.015\end{array}$ & $\begin{array}{l}0.151 \pm \\
0.018\end{array}$ & $\begin{array}{l}0.153 \pm \\
0.017\end{array}$ & $\begin{array}{l}0.159 \pm \\
0.014\end{array}$ & $\begin{array}{l}0.151 \pm \\
0.019\end{array}$ & $\begin{array}{l}0.162 \pm \\
0.019\end{array}$ & $\begin{array}{l}0.167 \pm \\
0.018\end{array}$ & $\begin{array}{l}0.147 \pm \\
0.016\end{array}$ & $\begin{array}{l}0.150 \pm \\
0.019\end{array}$ & $\begin{array}{l}0.173 \pm \\
0.019\end{array}$ & $\begin{array}{l}0.173 \pm \\
0.020\end{array}$ & $\begin{array}{l}0.162 \pm \\
0.016\end{array}$ & $\begin{array}{l}0.161 \pm \\
0.020\end{array}$ & $\begin{array}{l}0.170 \pm \\
0.020\end{array}$ & $\begin{array}{l}0.006 \pm \\
0.004\end{array}$ \\
\hline
\end{tabular}




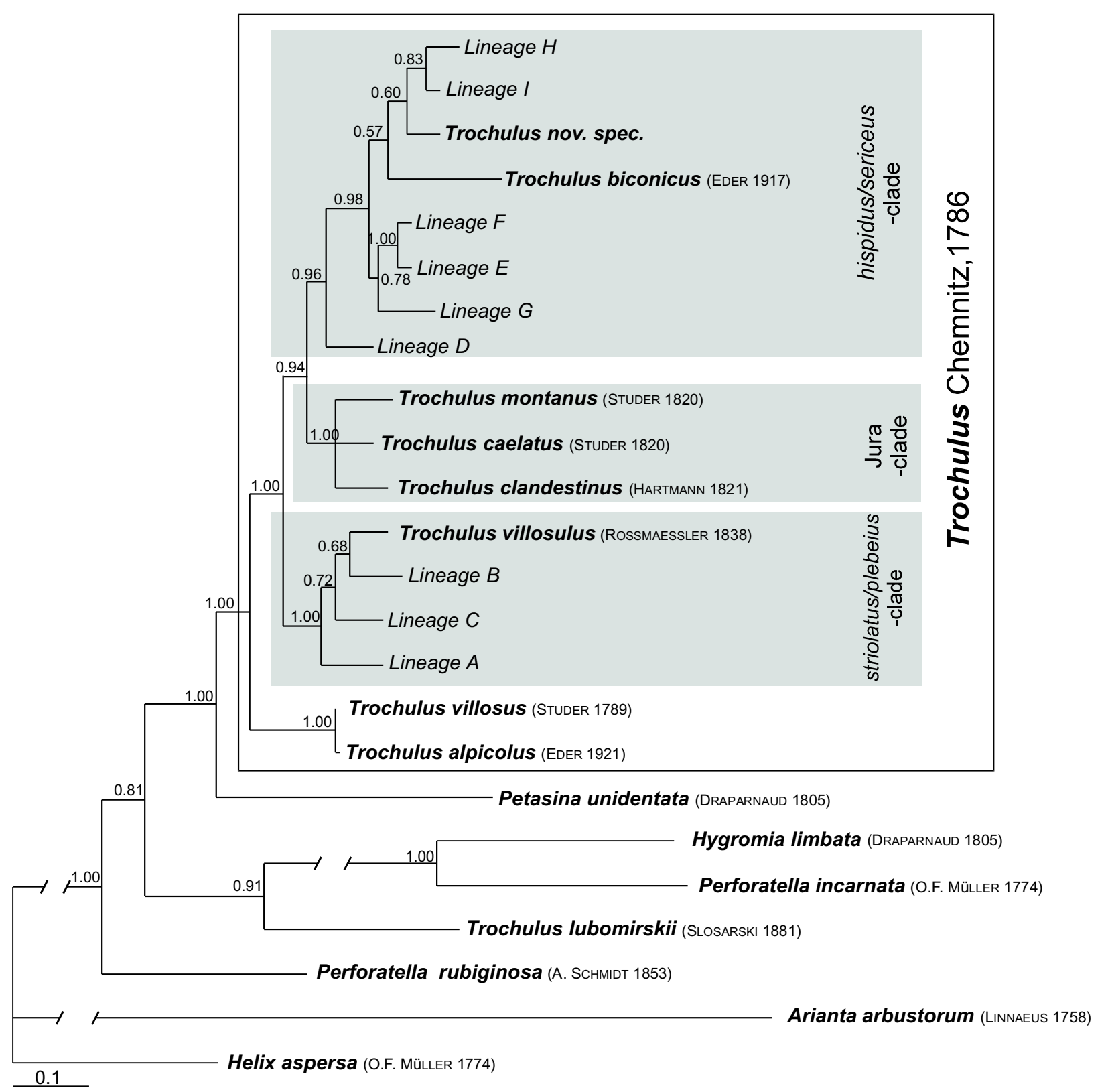

\section{Figure 2}

Consensus tree of $\mathbf{9 0 , 0 0 0}$ trees sampled by the Markov-chain in Bayesian analysis for the total data set (I383 bp of COI, I6S and ITSI). Numbers on nodes indicate the Bayesian posterior probabilities.

losses of hairs / habitat transitions had a higher probability (0.59) than the only other observed pattern of two losses/one gain or three losses/no gain (0.41).

\section{Functional analysis}

The analysis of variance showed that on a water-covered leaf surface, hairy shells required a significantly higher minimum force to overcome the adhesion $(\mathrm{F}=720$, d.f. $=$ $2, \mathrm{p}<0.00001)$. There was no difference on a dry surface $(\mathrm{F}=0.47$, d.f. $=2, \mathrm{p}=0.37$; Figure 5$)$.

\section{Discussion}

Considering the limited number of sites sampled, we found a relatively large number of lineages, most of which 


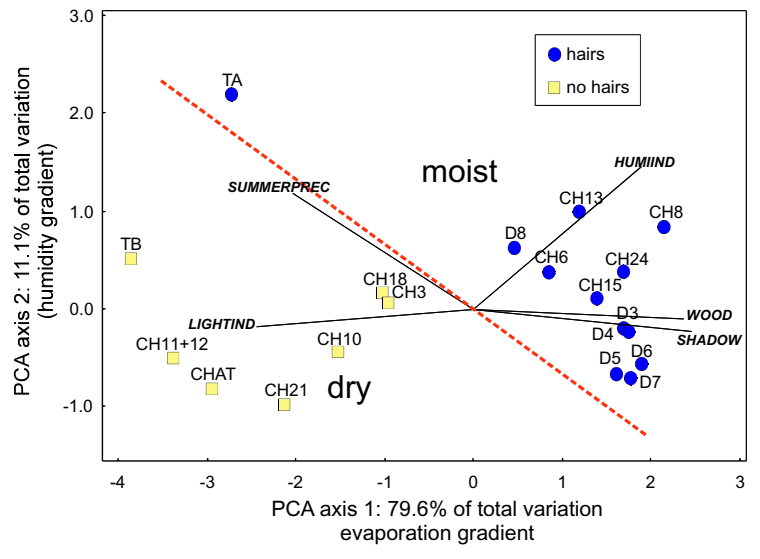

Figure 3

Two first components of the PCA of the sampled localities over 9 environmental variables. Black dots: populations with haired individuals. Open squares: populations with hair-less individuals. Sampling sites above the dotted line are considered moist whereas those under it are dry.

could not be attributed to described species. This suggests that many other more or less morphologically similar entities may exist throughout the range of the genus. The existence of cryptic lineages could explain at least in part the current taxonomic uncertainty in Trochulus [18-20]. For example, several subspecies have been described for $T$. striolatus [21], which may well represent distinct evolutionary lineages such as described here. Given that the sequence divergence among the nine unidentified lineages is of the same magnitude as among described, morphologically and ecologically distinct species (Figure 1, Table 2), it can be reasonably assumed that the cryptic lineages within the striolatus/plebeius and hispidus/sericeus clades correspond to good species. Even under the assumption of an exceptionally fast molecular clock in land snails of up to $5 \%$ sequence divergence per one million years [22], the lineages in the striolatus/plebeius clade, for example, persisted for at least two million years as independent evolutionary entities. The existence of more or less cryptic lineages or species is not an unusual finding in land snails [23-25]. In contrast to the high divergence of the unidentified lineages, the comparatively small genetic distance between T. villosus and T. alpicolus indicated a questionable specific distinction between these two taxa. Detailed phylogeographic analyses in addition to morphometric and ecological studies will be necessary to disentangle the species limits of these cryptic Trochulus complexes, clarify the taxonomy and reveal their evolutionary history. In addition, the species T. lubomirskii, which was placed by Schileyko [26] into the subgenus Plicuteria, may not belong to the genus Trochulus at all.

A haired shell appears as the ancestral state in the genus Trochulus. This inference is strengthened by the observation that some of the hair-less species do possess some as juveniles. During the evolutionary history of the genus Trochulus, hairs appear to have been lost several times independently (Fig. 3, Table 1) and this was always correlated with a shift in habitat (i.e. hairs are only present in moist habitats, mostly woodlands). This suggests that hairs potentially have an adaptive function in humid habitats and once the presumed selective pressure for the maintenance of these costly protein structures is relieved, they are lost. Such a correlation makes certain potential adaptive explanations for hairiness unlikely: defence against predators or mechanical stability have no obvious reasons to co-vary with the humidity characteristics of a habitat.

The facilitation of locomotion by decreasing the adhesion to water films in humid environments had been previously hypothesised to be the selective advantage of a haired shell $[14,15]$. However, the results of our experiments have shown that the opposite is true. The presence of hairs significantly increased the minimum force necessary to move shells over wet surfaces. Having thus shown that the initial hypothesis [14] is at least in this case not applicable, we propose an alternative: haired shells may confer an selective advantage by increasing the adhesion to the water film on the unstable, moving leaves of their feeding plants during foraging (Figure 5). Indeed, snails are mostly active during phases of high ambient humidity [27] when leaves are covered with a water film due to rain, fog or dew. This water film is usually in contact with the shell during locomotion (Figure 6). Observation shows that Trochulus species in moist habitats preferentially forage on large-leaved herbaceous plants like Adenostyles, Urtica, Homogyne or Tussilago [28]. Hence, falling off the leaf and needing to crawl up again to this feeding site (that can be one meter above ground) represents a considerable effort given the exceedingly costly and ineffective locomotion of land snails [29]. In dry habitats on the contrary, snail species avoid the hard plant matter typical for this habitat and preferentially feed on dead material lying on the ground $[28,30]$, where a mechanism increasing shell adhesion offers no obvious advantage to its bearer. This interpretation is supported by the fact that phylogenetically distantly related haired species, such as Helicodonta obvoluta and Isognomostoma isognomostoma, are found in the same habitats and have in general similar life-styles [31]. However, as long as the positive effect of increased adherence to food plants on the individual fitness is not proven, this remains a hypothesis and does not preclude 
Table I: Table of sampling sites, presumed taxon, habitat characterisation and presence or absence of hairs.

\begin{tabular}{|c|c|c|c|c|c|c|}
\hline Sampling site & Abbreviation & $\begin{array}{l}\text { Geographical } \\
\text { position }\end{array}$ & Presumed taxon & Habitat & Humidity & Hairs \\
\hline Burgsinn, Bayern, Germany & D3 & $\begin{array}{l}50^{\circ} 09^{\prime} 31 " \mathrm{~N} \\
09^{\circ} 40^{\prime} 34^{\prime \prime} \mathrm{E}\end{array}$ & T. striolatus/plebeius & wood & moist & yes \\
\hline Habichtstal, Bayern, Germany & D4 & $\begin{array}{l}50^{\circ} 02^{\prime} 54^{\prime \prime N} \\
09^{\circ} 25^{\prime} 4 \text { I"E }\end{array}$ & T. striolatus/plebeius & wood & moist & yes \\
\hline Dommershausen, Rheinland-Pfalz, Germany & D5 & $\begin{array}{l}50^{\circ} 07^{\prime} 45^{\prime \prime N} \\
07^{\circ} 23^{\prime} 47^{\prime \prime} \mathrm{E}\end{array}$ & T. striolatus/plebeius & wood & moist & yes \\
\hline Bingen, Rheinland-Pfalz, Germany & D6 & $\begin{array}{l}49^{\circ} 55^{\prime} 56 " \mathrm{~N} \\
07^{\circ} 58^{\prime} 57^{\prime \prime} \mathrm{E}\end{array}$ & T. striolatus/plebeius & wood & moist & yes \\
\hline Eltville, Hessen, Germany & D7 & $\begin{array}{l}50^{\circ} 0059^{\prime \prime} \mathrm{N} \\
08^{\circ} 04^{\prime} 28^{\prime \prime} \mathrm{E}\end{array}$ & $\begin{array}{l}\text { T. striolatus/plebeius } \\
\text { T. sericeus/hispidus }\end{array}$ & wood & moist & yes \\
\hline Büchsenberg, Baden-Württemberg, Germany & D8 & $\begin{array}{l}48^{\circ} 04^{\prime} 55^{\prime \prime N} \\
07^{\circ} 37^{\prime} 23^{\prime \prime} \mathrm{E}\end{array}$ & T. striolatus/plebeius & wood & moist & yes \\
\hline St. Seine l'Abbaye, Côte d'Or, France & MdO & $\begin{array}{l}47^{\circ} 26^{\prime} 04 " \mathrm{~N} \\
04^{\circ} 46^{\prime} 55^{\prime \prime} \mathrm{E}\end{array}$ & T. sericeus/hispidus & wood & - & yes \\
\hline La Neirigue, Fribourg, Switzerland & $\mathrm{CH} 3$ & $\begin{array}{l}46^{\circ} 42^{\prime} \mid 6^{\prime \prime} \mathrm{N} \\
06^{\circ} 55^{\prime} \mid 2^{\prime \prime} \mathrm{E}\end{array}$ & T. clandestinus & riverbank vegetation & moist & no \\
\hline Barrage des Rossens, Fribourg, Switzerland & $\mathrm{CH} 6$ & $\begin{array}{l}46^{\circ} 43^{\prime} 33^{\prime \prime} \mathrm{N} \\
07^{\circ} 06^{\prime} 55^{\prime \prime} \mathrm{E}\end{array}$ & T. sericeus/hispidus & wood & moist & yes \\
\hline Gorges de la Jogne, Fribourg, Switzerland & $\mathrm{CH} 8$ & $\begin{array}{l}46^{\circ} 36^{\prime} 45^{\prime \prime} \mathrm{N} \\
07^{\circ} 07^{\prime} I 0^{\prime \prime} \mathrm{E}\end{array}$ & T. sericeus/hispidus & gorge & moist & yes \\
\hline Ste Croix, Vaud, Switzerland & $\mathrm{CHIO}$ & $\begin{array}{l}46^{\circ} 50^{\prime} 44^{\prime \prime} \mathrm{N} \\
06^{\circ} 32^{\prime} 02^{\prime \prime} \mathrm{E}\end{array}$ & T. montanus & open wood & dry & no \\
\hline La Côte aux Fées, Neuchâtel, Switzerland & $\mathrm{CHII}+\mathrm{I} 2$ & $\begin{array}{l}46^{\circ} 50^{\prime} 74 " \mathrm{~N} \\
06^{\circ} 32^{\prime} 42^{\prime \prime} \mathrm{E}\end{array}$ & T. montanus & grassland & dry & no \\
\hline Col des Mosses, Vaud, Switzerland & $\mathrm{CHI} 3$ & $\begin{array}{l}46^{\circ} 25^{\prime} 49 " \mathrm{~N} \\
07^{\circ} 08^{\prime} 22^{\prime \prime} \mathrm{E}\end{array}$ & T. villosus & wood & moist & yes \\
\hline Vallée du Rhône, Vaud, Switzerland & $\mathrm{CHI5}$ & $\begin{array}{l}46^{\circ} 19^{\prime} 43^{\prime \prime} \mathrm{N} \\
06^{\circ} 13^{\prime} 39^{\prime \prime} \mathrm{E}\end{array}$ & T. sericeus/hispidus & wood & moist & yes \\
\hline Sensetal, Bern, Switzerland & $\mathrm{CHI} 8$ & $\begin{array}{l}46^{\circ} 49^{\prime} 46^{\prime \prime} \mathrm{N} \\
07^{\circ} 19^{\prime} \mid 9^{\prime \prime} \mathrm{E}\end{array}$ & T. clandestinus & riverbank vegetation & dry & no \\
\hline Birseschlucht, Bern, Switzerland & $\mathrm{CH} 2 \mathrm{I}$ & $\begin{array}{l}47^{\circ} 17^{\prime} 54^{\prime \prime} \mathrm{N} \\
07^{\circ} 23^{\prime} 00^{\prime \prime} \mathrm{E}\end{array}$ & T. caelatus & cliff & dry & no \\
\hline Birseschlucht, Bern, Switzerland & $\mathrm{CH} 24$ & $\begin{array}{l}47^{\circ} 16^{\prime} 56^{\prime \prime N} \\
07^{\circ} 23^{\prime} \mid 3^{\prime \prime} \mathrm{E}\end{array}$ & T. sericeus/hispidus & wood & moist & yes \\
\hline Château d'Oex, Vaud, Switzerland & CHAT & $\begin{array}{l}46^{\circ} 16^{\prime} 23^{\prime \prime N} \\
07^{\circ} 2 I^{\prime} 42^{\prime \prime E}\end{array}$ & T. nov. spec. & alpine meadow & dry & no \\
\hline Bannalppass, Nidwalden, Switzerland & TA & $\begin{array}{l}46^{\circ} 53^{\prime} 40^{\prime \prime N} \\
08^{\circ} 27^{\prime} 15^{\prime \prime E}\end{array}$ & T. alpicolus & alpine meadow & moist & yes \\
\hline Bannalppass, Nidwalden, Switzerland & TB & $\begin{array}{l}46^{\circ} 53^{\prime} 43^{\prime \prime N} \\
08^{\circ} 27^{\prime} 2 I^{\prime \prime E}\end{array}$ & T. biconicus & alpine meadow & dry & no \\
\hline $\begin{array}{l}\text { Velká Javořina, Velká nad Veličkou, Czech } \\
\text { Republic }\end{array}$ & TVJ & $\begin{array}{l}48^{\circ} 5 \text { I'26"N } \\
17^{\circ} 39^{\prime} \mid \text { II"E }\end{array}$ & T. villosulus & wood & moist & yes \\
\hline Bohuslavice u Zlína, Czech Republic & PLB & $\begin{array}{l}49^{\circ} 09^{\prime} 19^{\prime \prime} \mathrm{N} \\
17^{\circ} 37^{\prime} 29^{\prime \prime} \mathrm{E}\end{array}$ & T. lubomirskii & meadow & - & yes \\
\hline
\end{tabular}

additional or even other adaptive functions of haired shells.

\section{Conclusion}

The present comparative analysis suggested that hairs on the shell confer a selective advantage in humid habitats only and are thus lost in drier habitats. In other words, the variability of hairiness within the genus Trochulus could be explained in terms the loss of its adaptive function in a selectively different environment.

\section{Methods}

\section{Taxon sampling}

Analyses were undertaken on twelve of the about 15 currently recognised species presumed to belong to the genus Trochulus s. str. Chemnitz, 1786 (Hygromiidae, Stylommatophora). However, the exact number of existing species is not known, because the species limits of the widely distributed T. hispidus and T. sericeus on the one hand and $T$. plebeius and T. striolatus on the other are equivocal $[19,20]$, the validity of several described taxa is disputed 


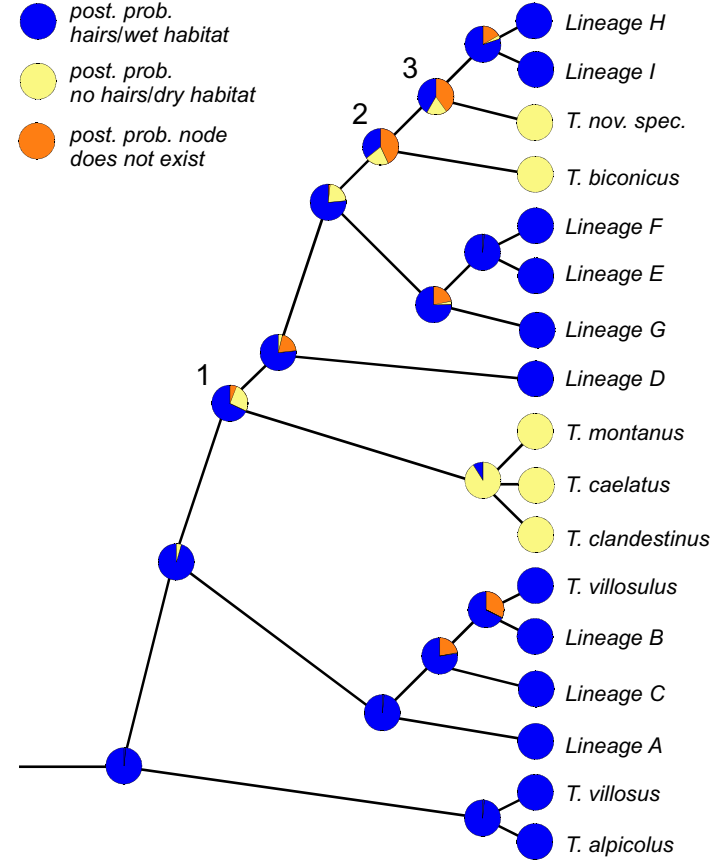

Figure 4

Bayesian reconstruction of ancestral states (hairs/no hairs, moist/dry habitat, respectively) on the topology of the Bayesian consensus tree (restricted to the Trochulus-clade).

$[18,32]$ and newly discovered species are not yet formally described (Pfenninger, unpublished data). Since initial analyses showed the existence of cryptic lineages, several populations for each of the putative species were sampled (Table 1). Four species from other genera of the subfamily Hygromiinae and two species of the family Helicidae were used as potential outgroups [33] (GenBank accession numbers AY546263, AY546343, AY546303, AY546284, AY546364, AY546324, AY546283, $\underline{\text { AY546363, }}$

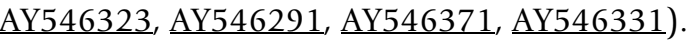

\section{DNA sequencing, lineage identification and phylogenetic analysis}

Entire snails were crushed and vortexed in 10\% w/v laundry detergent solution for storage at room temperature and tissue digestion [34]. For 78 individuals, a 512 bp segment of the cytochrome oxidase subunit I gene (COI) was amplified with PCR and sequenced. For selected individuals representing the major evolutionary lineages inferred in the previous analysis, a 362 bp fragment of the large subunit mitochondrial ribosomal gene (16S) and 509 bp of the internal transcribed spacer 1 (ITS-1) from the nuclear ribosomal cluster were additionally amplified and sequenced. An amount of 0.2 to $1 \mathrm{ng}$ total DNA (quanti-

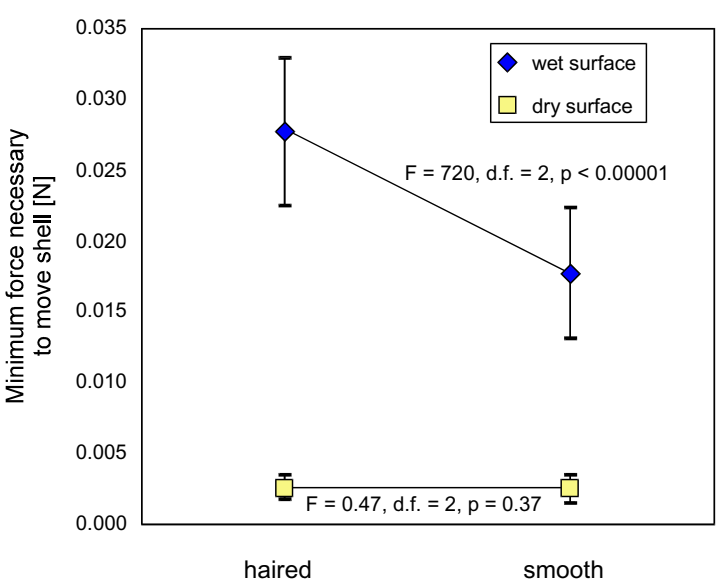

Figure 5

Mean (+/- s.d.) minimum necessary force to move haired and smooth shells on wet and dry leaf surfaces.

fied on a $1 \%$ agarose gel using a $\lambda$ Hind III marker) were used as template in polymerase chain reaction (PCR). Specific PCRs were performed with the primers, amplification conditions and temperature profiles shown in Table 2. Primers were used for both specific PCR and subsequential automated direct sequencing. PCR products were purified using E.N.Z.A. Cycle Pure Kit (peqlab, Erlangen, Germany). Ten ng per sample were subjected to cycle sequencing using the ABI Prism Big Dye terminator kit (Perkin-Elmer, Norwalk, CT, USA). Sequencing reactions were electrophoresed on an ABI 377 automated DNA sequencer. In order to verify the results, gene products were sequenced in both directions and the two strands were aligned with SEQUENCE NAVIGATOR 1.0.1 (Perkin-Elmer, Norwalk, CT, USA). Sequences were deposited in GenBank under accession numbers DQ217794DQ217831. The orthologous DNA sequences were initially aligned using the default settings of CLUSTAL X [35] and optimised by eye. The most likely models of sequence evolution and their parameters according to the Akaike information criterion were inferred for each DNA data partition using MODELTEST v. 3.4 [36]. In an initial analysis, we used the COI data set to identify evolutionary lineages. A 99.9\% credible set of phylogenetic trees was estimated with the program MRBAYES [37] by sampling the tree space using a Metropolis coupled Monte Carlo Markov chain, implementing a $\mathrm{TN}+\mathrm{I}+\Gamma$ model of $\mathrm{COI}$ sequence evolution (where TN denotes Tamura-Nei, $\Gamma$ is the shape parameter of the gamma distribution and I the proportion of invariant sites). Initial runs as well as a posterior inspection of the likelihoods in the final run showed that a burn-in phase of 10,000 generations was largely sufficient for both analyses to allow the likelihood 


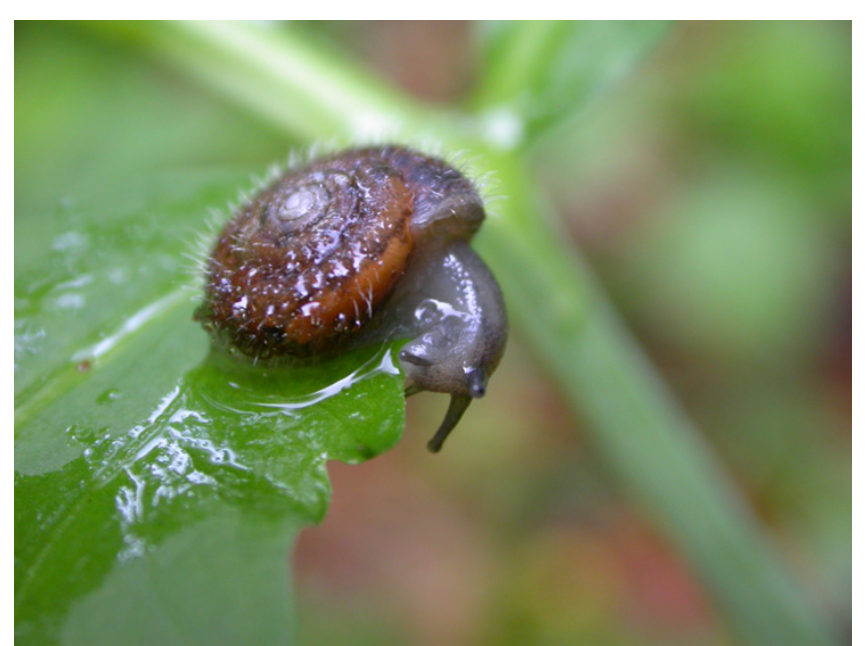

Figure 6

Active T. villosus foraging on a leaf. Note that the waterfilm on the leaf is adhering to the shell.

values to reach convergence. The chain was run for $10,000,000$ generations and sampled every $100^{\text {th }}$ generation. An unrooted majority consensus tree was computed from the sampled trees, excluding the trees sampled in the burn-in phase. The procedure was repeated for the phylogenetic data set where the Markov chain was run with separate models of sequence evolution for each data partition (GTR (general time reversible) $+\mathrm{I}+\mathrm{G}$ for $16 \mathrm{~S}$ and TVM (transversional model) $+\Gamma$ for ITS-1). Outgroup status was assigned to Helixaspersa [33].

\section{Correlation of habitat humidity with shell hairiness}

The direct estimation of humidity levels for sampling sites is difficult without long-term observation. However, the precipitation regime, habitat structure and vegetation at a sampling site can give clues on the degree of humidity experienced by the snails. For this behalf, five variables were recorded for all but one population belonging to Trochulus s.str. species. To characterise the microhabitat conditions, the mean light- and humidity indicator values [38] of the three most abundant herbaceous plant species at each sampling site were recorded (variables LIGHTIND and HUMIND). The evaporation regime is strongly influenced locally by the exposure to sun and wind, which was accounted for by characterising each sampling site as either i) entirely shadowed (2), partially or sometimes shadowed (1) and never shadowed (0) (variable SHADOW) and either ii) situated in a closed wood (2), open wood or forest edge (1) or not in a wood (0) (variable WOOD). Ultimately, the humidity conditions of a site depend on the precipitation in the area. As Trochulus species are active mainly during summer, we have recorded the average long-term precipitation from April to September (variable SUMMERPREC). This information was extracted from the climate layers with a spatial resolution of $0.5 \mathrm{~min}$ implemented in the computer program DIVAGIS version 4.2 for the spatial analysis of biodiversity [39]. The variables were summarised in a principal component analysis (PCA).

For all Trochulus s.str. populations investigated, the presence or absence of hairs on the shell of at least 10 adult individuals was recorded. As the hairs may wear off during adulthood (although rarely completely), the lack of the typical hair pits in the fine sculpture of the shell was taken as evidence for their principal absence. The presence or absence of hairs of the respective populations was then plotted on the PCA ordination.

Table 3: Primers used for specific PCR and direct sequencing, amplification conditions and temperature profiles.

\begin{tabular}{|c|c|c|c|}
\hline Primer & Sequence & amplification conditions & temperature profile \\
\hline COI universal [43] & $\begin{array}{l}\text { 5'- } \\
\text { GGTCAACAATCATAAAGATAT } \\
\text { TGG-3' 5'- } \\
\text { TAAACTTCAGGGTGACCAAA } \\
\text { AAATCA-3' }\end{array}$ & $\begin{array}{l}\text { total volume } 25 \mu \text { l with: } 0.17 \mathrm{mM} \\
\text { dNTPs } 3 \mathrm{mM} \mathrm{MgCl} \text { in I } \times \text { PCR } \\
\text { buffer } 0.13 \mu \mathrm{M} \text { of each primer I } \\
\text { unit Taq polymerase (Invitrogen) }\end{array}$ & $\begin{array}{l}\text { I cycle of } 2.5 \text { min at } 94^{\circ} \mathrm{C} \\
40 \text { cycle } 30 \mathrm{~s} \text { at } 90^{\circ} \mathrm{C} \\
\text { I min at } 48^{\circ} \mathrm{C} \\
\text { I min at } 72^{\circ} \mathrm{C} \\
\text { I cycle of } 10 \text { min at } 72^{\circ} \mathrm{C}\end{array}$ \\
\hline I6S universal [44] & $\begin{array}{l}\text { 5'-CGGCCGCCTGTTT } \\
\text { ATCAAAAACAT-3' 5'- } \\
\text { GGAGCTCCGGTTTGAACTCA } \\
\text { GATC-3' }\end{array}$ & $\begin{array}{l}\text { total volume } 15 \mu \mathrm{l} \text { with: } 0.1 \mathrm{mM} \\
\mathrm{dNTPs} 2.5 \mathrm{mM} \mathrm{MgCl}_{2} \text { in I } \times \mathrm{PCR} \\
\text { buffer } 0.2 \mu \mathrm{M} \text { of each primer } 0.5 \\
\text { unit Taq polymerase (Invitrogen) }\end{array}$ & $\begin{array}{l}\text { I cycle of } 2.5 \mathrm{~min} \text { at } 90^{\circ} \mathrm{C} \\
10 \text { cycles of } 50 \mathrm{~s} \text { at } 92^{\circ} \mathrm{C} \\
30 \mathrm{~s} \text { at } 44^{\circ} \mathrm{C} \\
40 \mathrm{~s} \text { at } 72^{\circ} \mathrm{C} \\
36 \text { cycles of } 30 \mathrm{~s} \text { at } 92^{\circ} \mathrm{C} \\
40 \mathrm{~s} \text { at } 48^{\circ} \mathrm{C} \\
40 \mathrm{~s} \text { at } 72^{\circ} \mathrm{C} \\
\text { I cycle of } 3 \text { min at } 72^{\circ} \mathrm{C}\end{array}$ \\
\hline ITS-I mollusc specific [45] & $\begin{array}{l}\text { 5'- } \\
\text { TAACAAGGTTTCCGTAGGTG } \\
\text { AA-3' } \\
\text { 5'GCTGCGTTCTTCATCGATG } \\
\text { C-3' }\end{array}$ & $\begin{array}{l}\text { total volume } 15 \mu \mathrm{l} \text { with: } 0.3 \mathrm{mM} \\
\mathrm{dNTPs} 2.5 \mathrm{mM} \mathrm{MgCl}_{2} \text { in I } \times \mathrm{PCR} \\
\text { buffer } 0.18 \mu \mathrm{M} \text { of each primer } 0.5 \\
\text { unit Taq polymerase (Invitrogen) }\end{array}$ & $\begin{array}{l}\text { I cycle of } 3 \text { min at } 94^{\circ} \mathrm{C} \\
40 \text { cycles of } 30 \mathrm{~s} \text { at } 92^{\circ} \mathrm{C} \\
30 \text { s at } 52^{\circ} \mathrm{C} \\
\text { I min at } 72^{\circ} \mathrm{C} \\
\text { I cycle of } 5 \text { min at } 72^{\circ} \mathrm{C}\end{array}$ \\
\hline
\end{tabular}




\section{Bayesian estimation of ancestral character states} In a first approach, we derived the posterior probability distribution of ancestral character states and their rate of change from 3000 trees sampled at random from the $99.9 \%$ credibility set of phylogenetic trees, using the Bayesian approach as implemented in the program MULTISTATEBAYES [40]. Applying an uninformative (uniform) prior on the rate parameter distribution, a Markov chain was run for 1,000,000 generations after it reached convergence. The estimated rate parameter ratio for both directions of character change as well as the reconstructed ancestral states for each internal node of the tree investigated was sampled every $200^{\text {th }}$ generation. This procedure estimates i) the probability that the ancestral node existed in the first place and ii) the probabilities of both character states at the respective node. These three probabilities sum up to 1 , thus simultaneously taking phylogenetic and character mapping uncertainty into account. In a second approach, the most parsimonious number of character state changes was reconstructed for each of the $99.9 \%$ credibility set of phylogenetic trees using the ANCESTRAL STATE RECONSTRUCTION module in MESQUITE [41]. The different reconstructions were then weighted according to the posterior probability of the corresponding tree [42].

\section{Adhesion experiments}

The minimum force necessary to move Trochulus shells (upwards oriented apex) with or without hairs over dry and wet, horizontal leaf surfaces was measured. For this behalf, we have chosen the largest species, T. villosus. It would have been desirable to use shells of other lineages as well, however, it was not possible to measure the force necessary to move smaller shells with the necessary accuracy. Twelve T. villosus shells were glued to thin nylon strings. The strings were led over a roll with a small aluminium basket fastened on the other end. Small weights were incrementally added to the basket until the shell began to slide. This was replicated five times for each shell on both water film covered and on dry surfaces. Then, the hairs were mechanically removed to obtain smooth shells and the procedure was repeated. For each condition, differences in minimum force needed to move the shells with or without hairs were tested for significance with an ANOVA design.

\section{Authors' contributions}

MP designed the study, collected parts of the material, performed the analyses and drafted the manuscript. MH contributed to the samples and carried out part of the molecular work. DS also contributed to the samples and participated in the statistical analyses. AD contributed samples, participated in the design of the study and helped to draft the manuscript. All authors were involved in preparation of the manuscript and approved the final version.

\section{Acknowledgements}

We thank Holger Geupel for technical assistance. MP acknowledges the financial support of the A. Messer Stiftung. Jacques Hausser, Aris Parmakelis, Christian Albrecht and an anonymous referee gave valuable comments on the manuscript. We thank Margret Gosteli and the Museum of Natural History in Bern for samples and additional information.

\section{References}

I. Harvey P, Pagel MD: The comparative method in evolutionary biology Oxford: Oxford University Press; 1991.

2. Porter ML, Crandall KA: Lost along the way: the significance of evolution in reverse. Trends Ecol Evol 2003, I 8:54 I-547.

3. Vermeij GJ: A natural history of shells Princeton: Princeton University Press; 1995.

4. Godan D: Molluscs: Their significance for science, medicine, commerce and culture Berlin: Parey; 1999.

5. Palmer AR: Quantum changes in gastropod shell morphology need not reflect speciation. Evolution 1985, 39:699-705.

6. Hellberg ME, Balch DP, Roy K: Climate-driven range expansion and morphological evolution in a marine gastropod. Science 2001, 292: 1707-1710.

7. West KCA: Morphology and behavior of crabs and gastropods from Lake Tanganyika, Africa: Implications for lacustrine predator-prey coevolution. Evolution I991, 45:589-607.

8. Britton JC: The relationship between position on shore and shell ornamentation in $\mathbf{2}$ size-dependent morphotypes of Littorina striata, with an estimate of evaporative water-loss in these morphotypes and in Melarhaphe neritoides. Hydrobiologia 1995, 309:129-142.

9. Wilson $A B$, Glaubrecht M, Meyer A: Ancient lakes as evolutionary reservoirs: evidence from the thalassoid gastropods of Lake Tanganyika. Proc R Soc Lond Ser B-Biol Sci 2004, 27 I:529-536.

10. Schilthuizen $M$ : Sexual selection on land snail shell ornamentation: a hypothesis that may explain shell diversity. BioMedCentral Evolutionary Biology 2003, 3:13.

II. Goodfriend GA: Variation in land-snail shell form and size and its causes - a Review. Systematic Zoology 1986, 35:204-223.

12. Saleuddin ASM: Ultrastructural studies on formation of periostracum in Helix aspersa (Mollusca). Calcified Tissue Research 1976, 22:49-65.

13. Wade CM, Mordan PB, Clarke B: A phylogeny of the land snails (Gastropoda: Pulmonata). Proc R Soc Lond B 2000, 268:4 I3-422.

14. Suvorov AN: Some mechanisms of adaptation to the wet microhabitats in higher geophila (Mollusca, Pulmonata). Zhurnal Obshchei Biologii 1999, 60:177-188.

15. Solem A: The shell makers New York: John Wiley \& Sons; 1974.

16. Ronquist F: Bayesian inference of character evolution. Trends Ecol Evol 2004, I 9:475-48I.

17. Baxter ML: The promise of a DNA taxonomy. Philosophical Transactions of the Royal Society of London - Series B: Biological Sciences 2004, 359:669-679.

18. Falkner G: Trichia (Trichia) graminicola n.sp. aus Südbaden (Gastropoda: Helicidae). Archiv für Molluskenkunde 1973, 1 03:209-227.

19. Forcart L: New researches on Trichia hispida (Linnaeus) and related forms. Proceedings of the first European Malacological Congress 1962:79-93.

20. Perrin N, Honsberger P, Pontet A: Approche biochimique et morphologique des espèces du genre Trichia (Helicidae, Gastropoda) de Suisse occidentale. Revue Suisse de Zoologie 1984 92:483-495

2I. Falkner G: Beiträge zur Nomenklatur der europäischen Binnenmollusken, VIII: Nomenklaturnotizen zu europäischen Hygromiidae (Gastropoda: Stylommatophora). Heldia I995, 2:97-107.

22. Thomaz D, Guiller A, Clarke B: Extreme divergence of mitochondrial DNA within species of pulmonate land snails. Proc $R$ Soc Lond Ser B-Biol Sci 1996, 263:363-368.

23. Pinceel J, Jordaens K, Pfenninger M, Backeljau T: Rangewide phylogeography of a terrestrial slug in Europe: evidence for Alpine 
refugia and rapid colonization after the Pleistocene glaciations. Mol Ecol 2005, I 4: I I33-I I 50.

24. Pfenninger M, Magnin F: Phenotypic evolution and hidden speciation in Candidula unifasciata ssp (Helicellinae, Gastropoda) inferred by $16 \mathrm{~S}$ variation and quantitative shell traits. Mol Ecol 200I, 10:254|-2554.

25. Wilke T, Duncan N: Phylogeographical patterns in the American Pacific Northwest: lessons from the arionid slug Prophysaon coeruleum. Mol Ecol 2004, I3:2303-23I5.

26. Schileyko AA: On the systematics of Trichia s. lat. (Pulmonata: Helicoidea: Hygromiidae). Malacologia 1978, 17:1-56.

27. Cook $\mathrm{A}$ : Behavioural Ecology: doing the right thing, in the right place at the right time. In The Biology of Terrestrial Molluscs Edited by: Barker GM. Oxon: CABI Publishers; 200I:447-488.

28. Frömming E: Biologie der Mitteleuropäischen Landgastropoden Berlin: Dunker \& Humbold;; 1954.

29. Denny M: Locomotion: the cost of gastropod crawling. Science 1980, 208: I 288-1290.

30. Kerney MP, Cameron RAD, Jungbluth JH: Die Landschnecken Nord- und Mitteleuropas Hamburg; Berlin: Paul Parey; 1983.

31. Speiser B: Food and feeding behaviour. In The Biology of Terrestrial Molluscs Edited by: Barker GM. Oxon: CABI Publishers; 200I:259-288

32. Gittenberger E, Neuteboom WH: On Trichia alpicola (Eder, 1921) from Switzerland (Mollusca: Gastropoda Pulmonata:Hygromiidae) and the spiral sculpture on its shell. Zoologische Mededelingen 1991, 65:247-250.

33. Steinke D, Albrecht C, Pfenninger M: Molecular phylogeny and character evolution in the Western Palaearctic Helicidea s.l. (Gastropoda, Stylommatophora). Molecular Phylogenetics \& Evolution 2004, 33:724-734.

34. Bahl A, Pfenninger M: A rapid method of DNA isolation using laundry detergent. Nucleic Acids Res 1996, 24:I587-I588.

35. Thompson JD, Gibson T], Plewniak F, Jeanmougin F, Higgins DG: The CLUSTAL_X windows interface: flexible strategies for multiple sequence alignment aided by quality analysis tools. Nucleic Acids Res 1997, 25:4876-4882.

36. Posada $D$, Crandall KA: MODELTEST: testing the model of DNA substitution. Bioinformatics 1998, 14:817-818.

37. Huelsenbeck JP, Ronquist F: Bayesian inference of phylogeny. Bioinformatics 200I, 17:754-755.

38. Ellenberg H, Weber HE, Düll R, Wirth V, Werner W, Paulißen D: Zeigerwerte von Pflanzen in Mitteleuropa 2nd edition. Göttingen: Goltze KG; 1992.

39. Hijmans RJ, Guarino L, Cruz M, Rojas E: Computer tools for spatial analysis of plant genetic resource data: I. DIVA-GIS. Plant Genetic Resources Newsletter 2001, I 27:15-19.

40. Pagel M, Meade A, Barker DM: Bayesian estimation of ancestral character states on phylogenies. Syst Biol 2004, 53:673-684.

41. Maddison WP, Maddison DR: Mesquite: a modular system for evolutionary analysis. Version I.05. 2004.

42. Huelsenbeck JP, Rannala B, Larget B: A Bayesian framework for the analysis of cospeciation. Evolution 2000, 54:352-364.

43. Folmer O, Black M, Hoeh $W$, Lutz R, Vrijenhoek R: DNA primers for amplification of mitochondrial cytochrome $c$ oxidase subunit I from diverse metazoan invertebrates. Mol Mar Biol Biotech 1994, 3:294-299.

44. Palumbi S, Martin A, Romano S, McMillan W, Stine O, Grabowski G: The simple fool's guide to $P C R$ version 2.0 Honolulu: University of Hawaii; 1991.

45. Armbruster GFJ, van Moorsel CHM, Gittenberger E: Conserved sequence patterns in the non-coding ribosomal ITS-I of distantly related snail taxa. J Molluscan Stud 2000, 66:570-573.
Publish with Bio Med Central and every scientist can read your work free of charge

"BioMed Central will be the most significant development for disseminating the results of biomedical research in our lifetime. "

Sir Paul Nurse, Cancer Research UK

Your research papers will be:

- available free of charge to the entire biomedical community

- peer reviewed and published immediately upon acceptance

- cited in PubMed and archived on PubMed Central

- yours - you keep the copyright
BiolMedcentral 